\title{
Status of Baby Born to Brain-dead Mother: Ethical and Logical Issues
}

\author{
Aleksandra Bendowska ${ }^{1}$, Agnieszka Żok ${ }^{2}$, Katarzyna Beata Głodowska ${ }^{3}$, \\ Dariusz Iżycki ${ }^{4}$, Ewa Baum ${ }^{2}$ \\ 1 Department of Social Sciences and the Humanities, Poznan University of Medical Sci- \\ ences, Poland \\ 2 Division of Philosophy of Medicine and Bioethics, Poznan University of Medical Sci- \\ ences, Poland \\ 3 History of Medical Professions Lab, Poznan University of Medical Sciences, Poland \\ 4 Department of Cancer Immunology, Poznan University of Medical Sciences, Poznan, \\ Poland
}

\begin{abstract}
The study aims to analyse the clinical proceedings in pregnant women diagnosed with brain death. Apart from the diagnostic premises and the patient's rights, the ontological status of the foetus proves to be a severe problem. In reference to the principles of zeroth-order logic, the assumption of potential used by personalists is not a tautology.
\end{abstract}

\section{Introduction}

Death and birth are often presented as two extremes that are mutually exclusive. However, the two philosophical and medical phenomena can overlap and coexist.

Advanced intensive care techniques have made it possible to support the vital functions of patients diagnosed with brain death. These methods are used to temporarily support the respiratory and circulatory functions of people who may become organ donors. They are also used in suspected brain death in pregnant women in order to extend the duration of gestation, and thus increase the survival chances of the foetus.

Respect for both the mother's and the foetus's autonomy in a situation where the mother cannot express her will requires particularly careful handling not only in the medical but also in the ethical and legal terms. Every decision should involve those who are close to the patient and who will be able to take care of the child in the future. The issue is a very complex one 


\section{Aleksandra Bendowska et al.}

and can evoke extreme emotional responses, not only among the patient's relatives but also among medical personnel and even the public.

From a medical point of view, the medical professionals who provide care to a patient with suspected brain death should refer to the classical standards and guidelines of care for organ donors. These measures are used to postpone the somatic disintegration of the body and the subsequent asystole. However, any such procedure should be modified to ensure the wellbeing of the foetus.

From a medical, ethical and social perspective, it is a success to manage a pregnancy in such a way that it culminates in the birth of a living child with as few complications as possible caused by prematurity or treatment. On the other hand, failure in this respect, understood as premature birth and the associated neurological consequences for the child, raises the question of the limits of medical procedures. In view of these doubts, each case should be considered individually and consulted within an interdisciplinary team.

Another problem is the ontological status of the foetus. From a purely logical point of view, the personalists' premise of its potentiality is incorrect in its reference to the reductio ad absurdum argument $(p \Rightarrow \neg p) \Rightarrow \neg p$ (Kmita, 1969-197; Kmita, 1977; Różyńska, 2008). Therefore, if potentiality of the foetus is assumed, and if the embryo/foetus develops normally, it is possible to assume that it will become a human in the future. It is important to remember, however, that 70 percent of pregnancies end in natural, spontaneous miscarriage or that the foetus can transform into molar pregnancy. This contradiction makes it impossible to accept the assumption of potentiality as real in the logical sense.

The cited example additionally weakens the potentiality argument. Its proponents are wont to claim that the foetus has the potentiality to become a human, as long as nothing disturbs it (Różyńska, 2008). Hence the question: What if the assistance it must be given to keep it alive goes beyond the standards of prenatal treatment? Subsequently, the right to life does not have to be connected to its potentiality, but rather, to the will and ability of the decision-making subject. This assumption makes it possible to undertake an analysis of the social and ethical dilemmas associated with life support in pregnant women.

\section{Materials and Methods}

The paper addresses the problem of the right to decide about a pregnant woman and a foetus, as well as the clinical dilemmas that affect such 
decisions. It includes an analysis of research papers available in PubMed (key words: pregnant women, brain death, brain damage, brain injury), and of legislation and literature in the area of philosophy and ethics.

The method used (key to resolving the discussed dilemmas) was an indepth analysis of legislation which, by way of direct reference to cultural and philosophical aspects, was of hermeneutical character.

\section{Brain Death Issues}

As early as in the ancient times, Galen of Pergamon (129-199) identified three key organs which he called atria mortis, or the atria of death, namely the heart, the brain and the lungs. In Greek culture, a lack of respiratory function was considered the beginning of death.

In modern times, it was not until 1968 that a diagnostic procedure for brain death was proposed in A Definition of Irreversible Coma. Report of Ad Hoc Committee of the Harvard Medical School to Examine the Definition of Brain Death. The criteria presented in the report were neither new nor particularly different from those proposed earlier. Nonetheless, this was a ground-breaking document that clearly established brain death as a new criterion of human death (Nair-Collins, 2015).

The effective legal acts in Poland that currently regulate the diagnosis of brain death are the Act of 5 December 1996 on the professions of doctors and dentists (Ustawa z dnia 5 grudnia 1996 r. o zawodach lekarza i lekarza dentysty, 1997), and the Act of 1 July 2005 on cell, tissue and organ recovery, storage and transplantation (Ustawa z dnia 1 lipca 2005 r. o pobieraniu, przechowywaniu i przeszczepianiu komórek, tkanek i narządów, 2005) with amendments introduced in 2017. Also, the Decree of the Minister of Health of 17 July 2007 on the criteria and method of diagnosing permanent irreversible brain activity cessation applied until 2017. The amended provisions of the decree were transposed to the aforementioned legal acts under the Act of 24 February 2017, amending the Act on the professions of doctors and dentists, and the Act on cell, tissue and organ recovery, storage and transplantation.

Brain death is diagnosed in accordance with the Act on the professions of doctors and dentists, pursuant to a decree of the minister responsible for health affairs. At least every five years, the minister entrusts specialists with the evaluation of the method for pronouncing death. In accordance with the provisions of the Act of 24 February 2017, the criteria announced in 2007 will apply until the announcement of a new decree by the Minister of Health. 


\section{Aleksandra Bendowska et al.}

The diagnosis of brain death is, therefore, based on the diagnosing of irreversible loss of brain function, which is conducted in two stages: Stage 1: suspicion of brain death, Stage 2: performance of tests to confirm brain death.

In Poland, since 2017, permanent irreversible cessation of brain activity has to be unanimously pronounced by two medical specialists holding the second degree of specialisation or a specialist title, including one specialist in anaesthesiology and intensive care or neonatology, and the other in neurology, paediatric neurology, or neurosurgery.

Brain death is a rare phenomenon ( $<10 \%$ of all brain damage), and the incidence of brain death in pregnant women is even rarer. Suddaba et al. determined that only $2.8 \%$ of all brain death cases occur in pregnant women (Said et al., 2013).

There is no global register of such patients, and literature provides information on thirty-seven cases registered between 1982 and 2019. Cases of brain death in pregnant women have been reported in the United States, Finland, Italy, Germany, Switzerland, Spain, Chile, Ireland, Great Britain, Brazil, Argentina, Poland, the United Arab Emirates, Croatia, and Japan (Bush et al., 2003; Burkle et al., 2003; Esmaeilzadeh et al., 2010; Heikkinen et al., 1985; Hussein et al., 2016; Lane et al., 2004; Nishimura et al., 2016; Souza et al., 2006; Wawrzyniak et al., 2015; Woderska et al., 2012; Said, et al., 2013; Wróżyńska, 2019). It is suspected that a large number of case reports have not been published due to therapeutic failure or that no diagnosis of brain death was made due to the inability to perform full diagnostics (e.g. apnoea tests) (Said, et al., 2013).

The most common causes of brain death in pregnant women include: rupture of intracranial aneurysm, damage to arteriovenous brain malformations, and hypoxic-ischaemic encephalopathy associated with sudden cardiac arrest (Burkle et al., 2015).

According to the published case reports, the longest period of maintaining the vital functions in a brain-dead pregnant woman has been 110 days (Said et al., 2013). This is also one of the three cases in which the therapy started in the $16^{\text {th }}$ week of gestation and ended in the delivery of a living child (Esmaeilzadeh et al., 2010; Said et al., 2013). The average duration of therapy in an intensive care unit is 35 days.

Although the subject of death is present in public awareness, as indicated by surveys (Burkle et al., 2015), reflections on death do not have to go hand in hand with the knowledge of how end of life is pronounced. Some very interesting data in this respect was provided by a survey conducted in 2016 by the Public Opinion Research Centre (CBOS). According to the 
findings, nearly half of adult Poles (49\%) believe that death occurs when the brain is irreversibly damaged, while two fifths (40\%) are inclined towards the traditional understanding of death as cardiac arrest. Compared to 2012, the traditional understanding of death is less prevalent among respondents, and the effective legal and medical criterion is specified more often. In most of the analysed socio-demographic groups, the predominant notion is that death occurs when the brain is irreversibly damaged. The groups where this view is held include well-educated respondents, residents of the largest cities, respondents from households with the highest income per capita, and respondents who do not participate in religious practices and declare leftwing political orientation. On the other hand, the traditional approach has more supporters among the oldest respondents, residents of rural areas, and respondents with primary, lower secondary or basic vocational education (CBOS, 2016)

Despite such a high declared level of knowledge of the concept of brain death understood as human death, researchers point out that this declared knowledge is not reflected in social attitudes. Some people hold the suspicion that the concept of brain death was created only for the purpose of increasing the number of transplants. They accuse doctors of deliberately manipulating biological facts to achieve the socially desirable goal of increasing the number of organ donors (Bernat, 2014).

It is, nonetheless, difficult to agree with this view, since the criteria for pronouncing a person deceased as a result of brain death were created on the basis of state-of-the-art medical knowledge by specialists in many fields: anaesthesiology and intensive care, neurology, neurosurgery, and forensic medicine. The criteria are not a social postulate, a 'social contract' created by a group of stakeholders in such developments.

Amendments to the legal acts that regulate the principles of pronouncement of brain death and irreversible cardiac arrest have triggered a number of discussions in the media. The disputes, even those that regard purely legislative or linguistic issues, do not contribute to an improvement in the public perception. The definition of death based on a decree of the competent minister rather than a law is seen as controversial. However, this state of affairs was defended by Professor Roman Danielewicz who declared that the decree is an up-to-date and factual regulation which may be changed should new scientific findings emerge.

In light of the above, the problem can be seen as a lack of appropriate public policy and education at pre-university level.

The issue of treating a pregnant patient with suspected brain death is accompanied by many moral dilemmas. These are rooted in the lack of 


\section{Aleksandra Bendowska et al.}

a clearly described therapeutic process, as well as the status of the pregnant woman and her right to die. Another important issue are linguistic concerns. Medical professionals use various terms to describe such a braindead patient, for instance: a pregnant or terminally ill patient, a deceased person, a corpse, an organ donor or a living incubator (Finnerty, et al., 1999). The language they use reflect their perception of the world. Even if a pregnant woman who has been pronounced brain-dead is perceived as deceased or terminally ill in persistent vegetative state, it is still possible to inflict harm on her or to act to her disadvantage in a conscious or unconscious way. Everyone has the inalienable right to die in dignity, and the decision to save the foetus does not relieve the medical personnel and those involved in the care of the patient from the obligation to respect this right (Milliez et al., 2001).

Moreover, the decision to continue treatment may raise concerns regarding the instrumentalisation, manipulation, and objectification of the patient, which is evidenced by the fact that she can be called an 'incubator'. From the moment the decision is made, the patient's life functions are not maintained due to her state of health and do not serve her treatment, but rather that of the developing foetus. In this situation, there are many analogies to organ donation, but the difference is that the willingness to donate organs after death for transplantation purposes is usually regulated by law. In the case of pregnant women, there is no questionnaire that obliges patients to express their willingness to continue or stop treatment should they lose the ability to self-determine. Many researchers would consider such a declaration a very useful one. Nevertheless, it has not yet been unified, and therefore, it is the duty of the medical personnel to exercise due diligence in order to determine the patient's actual will (Burkle et al., 2015; Catlin \& Volat, 2009; Dickens, 2011; Finnerty et al., 1999). If this is impossible to determine, pursuant to the effective Polish law, in the case of a patient who is a minor or is incapable of giving informed consent, a doctor may carry out an examination or provide other health services, but to do so, they need the consent of the patient's statutory representative. If the patient does not have a statutory representative or if it is impossible to communicate with them, the doctor needs to obtain consent from a family court (Ustawa z dnia 5 grudnia 1996 r. o zawodach lekarza i lekarza dentysty, 1997).

From an ethical point of view, if the patient is a declared organ donor, the decision to continue artificial maintenance of their vital functions may be motivated by the fact that the foetus will be the first beneficiary of the mother's conscious donation (Esmaeilzadeh et al., 2010). 
The Polish Medical Code of Ethics imposes upon a doctor who treats a pregnant woman the duty of care for the health and life of her child also in the stage of prenatal development (Naczelna Izba Lekarska, 2004). Thus, from a medical and ethical perspective, the consequences of the decision to continue to provide care to the foetus should also be considered. This should include an assessment of the foetus's vitality and its chances of postnatal development. The birth of an extremely immature preterm baby or a child with numerous developmental defects should be considered as a treatment failure and as harm to the foetus. Such scenarios may affect decisions in favour of not performing medical interventions, such as caesarean sections, but signify consent to the death of the foetus in the uterus. Decisions such as this may be ethically justified in cases where the condition of the mother or foetus would not allow the pregnancy to continue while its culmination in a birth would pose a threat to the child's life and result in complications in its development (Milliez et al., 2001). This is an issue which leads to a dispute on the quality and sanctity of life, as well as to the question whether the life of the foetus should be saved at any cost or whether the chances of a healthy birth should be calculated.

Given the complexity of the dilemmas concerning brain death in pregnant women, the American College of Obstetricians and Gynaecologists (ACOG) published an opinion on end-of-life decision making. According to this opinion, doctors should support the autonomy of pregnant women and their decisions, unless the law provides otherwise. The opinion also stresses that a healthcare institution should not undermine the wishes of the patient, even if these are not expressed by the patient in person, but by her representative (Miller, 2015).

\section{Discussion}

Brain death in pregnant women usually gives rise to the dilemma of whether to artificially support the mother's vital functions in order to ensure the development of the foetus or to disconnect the medical equipment. It may seem that the decision to continue to support the mother's somatic functions should depend on the gestational age at which the symptoms of brain death occurred. However, relevant literature reports cases leading to the birth of a healthy new-born without neurological burdens where the mother's brain death was suspected at 16 weeks of gestation, as well as pregnancies in which irreversible brain damage was pronounced at 20 and 


\section{Aleksandra Bendowska et al.}

23 weeks, and which resulted in intrauterine death of the foetus or the birth of a child with serious neurological disorders (Said et al., 2013).

The latest systematic review of cases of pregnant women diagnosed with brain death was conducted in 2010 (Esmaeilzadeh et al., 2010). It included 30 cases, 11 of which ended with the delivery of a living new-born, and it is known that in 6 of these children, their psychomotor development during infancy and early childhood was not impaired.

All reported cases of pregnancies among women with irreversible damage to the brain stem ended in caesarean section, which is the optimal method of delivery in prolonged maternal somatic support, as it ensures the least traumatic birth for the foetus. The optimal timing for a caesarean section can be estimated by amniocentesis, which assesses foetal lung maturity (Haas et al., 2009; Rutkowska, 2012). Nevertheless, a case report of a pregnant woman with an irreversible brain stem injury in which spontaneous vaginal birth took place can be found in literature. The child received 6 and 8 points on the Apgar scale and was discharged 40 days after birth (Kinoshita et al., 2015).

Wood et al. examined the correlation between the degree of disability in children and the week of gestation at which they were born (Wood et al., 2000). Studies show that survival chances of new-borns delivered at 22, 23, 24, and 25 weeks of gestation are about $1 \%, 11 \%, 26 \%$, and $44 \%$, respectively, while the chances of survival without the burden of disability within a 30 -month perspective are $0.7 \%, 5 \%, 12 \%$, and $23 \%$, respectively. Other studies suggest that infant mortality is higher among preterm children born before the $32^{\text {nd }}$ week of gestation (Parry et al., 2003). Hence, it seems reasonable to continue a pregnancy in a suspected braindead patient until at least the $32^{\text {nd }}$ week. Nonetheless, the survival chances of an extremely immature foetus depend on many maternal factors and the obstetric procedures applied. Therefore, the decision to support the mother's vital functions should be made individually, and gestational age should not be the main determinant (Said et al., 2013).

The medical team should also take into account the safety and effects of the drugs used to maintain the mother's homeostasis on the developing foetus. Drugs used in intensive care may impair placental flow, cause foetal bradycardia, or induce uterine contractions leading to preterm labour.

Field et al. concluded that ethical considerations should justify the continuation of supporting the mother's somatic functions, despite the high costs of care in an intensive care unit and the difficulties in maintaining the mother's homeostasis (Field et al., 1988). Furthermore, studies have shown that artificial maintenance of the mother's vital functions in order to ensure 
the conditions for the foetus's development has a positive effect on shortening the new-born's stay in an intensive neonatal care unit, which is also advantageous from an economic point of view (Finnerty et al., 1999).

\section{Conclusion}

The principles of diagnosing brain death were developed by specialists based on the latest medical knowledge and accepted by the legislator as criteria for the death of the body as a whole. However, these criteria do not take into account the situation in which the diagnosed patient is a pregnant woman.

Therefore, in such a situation it is necessary to refer to the generally accepted principles of logic-based reasoning. Although the reference to zerothorder logic theory cannot be used to determine whether the foetus is a human, the rights of the patient and the chances of survival of the foetus must be considered. It should also be taken into account that professional medical care is essential for the survival of the foetus.

The aim of continuing to support the somatic functions of the mother is to conclude the gestation with the birth of a healthy new-born without any neurological burdens or disabilities. However, the complexity of the problems and dilemmas involved in the diagnosing of permanent irreversible brain damage makes it necessary to develop standards of conduct in such situations and to consider not only therapeutic, but also social and ethical contexts.

\section{R E F E R E N C E S}

Bernat, J. L. (2014). Whither Brain Death? The American Journal of Bioethics, 14(8), 3-8. doi: 10.1080/15265161.2014.925153

Burkle, Ch. M., Tessmer-Tuck, J., \& Wijdicks, E. F. (2015). Medical, legal and ethical challenges associated with pregnancy and catastrophic brain injury. Int J Gynaecol Obstet, 129, 276-280. doi: 10.1016/j.ijgo.2014.12.011

Bush,M. C., Nagy, S., Berkowitz, R. L., \& Gaddipati S. (2003). Pregnancy in a Persistent Vegetative State: Case Report, Comparison to Brain Death, and Review of the Literature. Obstet Gynecol Surv, 58(11): 738-748. doi: 10.1097/01.OGX.0000093268.20608.53

Catlin, A. J., \& Volat, D. (2009). When the Fetus is Alive but the Mother is Not: Critical Care Somatic Support as an Accepted Model of Care in the Twenty-First Century? Crit Care Nurs Clin N Am, 21, 267-276. doi: 10.1016/j.ccell.2009.01.004 
CBOS (2016). Postawy wobec transplantacji narzadów. Komunikat z badań nr 119/ 2016, Warszawa. Retrieved from http://cbos.pl/SPISKOM.POL/2016/K_ 119_16.PDF

Dickens, B. M. (2011). Brain death and pregnancy: FIGO Committee for the Ethical Aspects of Human Reproduction and Women's Health. Int J Gynaecol Obstet, 115(1), 84-85.

Esmaeilzadeh, M., Dictus, C., Kayvanpour, E., Sedaghat-Hamedani, E., Eichbaum, M., Hofer, S., Ahmadi, R. et al. (2010). One life ends, another begins. Management of a brain-dead pregnant mother - A systematic review. BMC Medicine, 8(74). doi: 10.1186/1741-7015-8-74

Finnerty, J. J., Chisholm, Ch. A., Chapple, H., Login, I. S., \& Pinkerton, J. V. (1999). Cerebral arteriovenous malformation in pregnancy: Presentation and neurologic, obstetric, and ethical significance. Am J Obstet Gynecol, 181(2), 296-303. doi: 10.1016/s0002-9378(99)70551-x

Field, D. R., Gates, E. A., Creasy, R. K., Jonsen, A. R., \& Laros, R. K. (1988). Maternal brain death during pregnancy. Medical and ethical issues. JAMA, 260(6), 816-822.

Haas, D. M., Imperiale, T. F., Kirkpatrick, P. R., Klein, R. W., Zollinger, T. W., \& Golichowski, A. M. (2009). Tocolytic therapy: a meta-analysis and decision analysis. Obstet Gynecol, 113, 585-594. doi: 10.1097/AOG.0b013e318199924a

Heikkinen, J. E., Rinne, R. I., Alahuhta, S. M., Lumme, J. A., Koivisto, M. E., Kirkinen, P.P., Järvinen, P.A. et. al. (1985). Life support for 10 weeks with successful fetal outcome after fatal maternal brain damage. BMJ, 290, 1237 1238. doi: 10.1136/bmj.290.6477.1237

Hussein, I. Y., Govenden, V., Grant, J. M., \& Said, M. R. (2006). Prolongation of pregnancy in a woman who sustained brain death at 26 weeks of gestation. BJOG, 113, 120-122. doi: 10.1111/j.1471-0528.2005.00801.x

Kinoshita, Y., Kamohara, H., Kotera, A., Sagishima, K., Tashiro, T., \& Niimori, D. (2015). Healthy baby delivered vaginally from a brain-dead mother. Acute Medicine \& Surgery, 2, 211-213. doi: 10.1002/ams2.95

Kmita, J. (1969-1970). Wykłady z logiki: dla studentów Wydziału Filologicznego, 2 tomy, wyd. Powielarnia i Introligatornia UAM, Poznań.

Kmita J. (1977). Wykłady z logiki i metodologii nauk. Państwowe Wydawnictwo Naukowe, Warszawa.

Naczelna Izba Lekarska (2004). Kodeks Etyki Lekarskiej. Retrieved from https:// www.nil.org.pl/dokumenty/kodeks-etyki-lekarskiej

Lane, A., Westbrook, A., Grady, D., O’Connor, R., Counihan, T. J., Marsh, B., \& Laffey, J. G. (2004). Maternal brain death: medical, ethical and legal issues. Intensive Care Med, 30, 1484-1486. doi: 10.1007/s00134-004-2305-6

Miller, L. A. (2015). Death and the pregnant woman. A true dilemma. J Perinat Neonatal Nurs, 29(4), 273-274. doi: 10.1097/JPN.0000000000000131

Milliez, J., \& Cayol, V. (2001). Palliative care with pregnant women. Best Pract Res Clin Obstet Gynaecol, 15(2), 323-331. doi: 10.1053/beog.2000.0172 
Nair-Collins M. (2015). Clinical and ethical perspectives on brain death. Medicoleg Bioeth, 5, 69-80. doi: 10.2147?MB.S70369

Nishimura, T., Kohama, K., Osako, T., Yamada, T., Tanaka, H., Nakao, A., \& Kotani, J. (2016). Case of 24-week Fetus Delivered from Mother on Life Support with Brain-death from Suicide Attempt: Ethical Issues Associated with Severe Complications. Acta Med Okayama, 70(5), 389-392. doi: $10.18926 / \mathrm{AMO} / 54598$

Parry, G., Tucker, J., \& Tarnow-Mordi, W. (2003). CRIB II: An update of the clinical risk index for babies score. Lancet, 361, 1789-1791. doi: 10.1016/S01406736(03)13397-1

Rutkowska, M. (2012). Recommendations regarding treatment of mother and newborn at the limit of viability considering ethical aspects. Perinatol Neonatol Ginekol, 5(1), 5-13.

Różyńska J., (2008). Od zygoty do osoby. Potencjalność, odentyczność i przerywanie ciąży. Stowo.Obraz terytoria, Gdańsk.

Said, A., Amer, A. J., Masood, U. R., Dirar, A., \& Faris, Ch. (2013). A brain-dead pregnant woman with prolonged somatic support and successful neonatal outcome: A grand rounds case with a detailed review of literature and ethical considerations. Int J Crit Illn Inj Sci, 3(3), 220-224. doi: 10.4103/22295151.119205

Souza, J. P., Oliveira-Neto, A., Surita, F. G., Cecatti, J. G., Amaral, E., \& Pinto e Silva, J. L. (2006). The prolongation of somatic support in a pregnant woman with brain-death: a case report. Reprod Health, 3(3). doi: 10.1186/1742-4755-3-3

Ustawa z dnia 5 grudnia 1996 r. o zawodach lekarza i lekarza dentysty (1997). Dz.U. $1997 \mathrm{Nr} 28$ poz. 152.

Ustawa z dnia 1 lipca 2005 r. o pobieraniu, przechowywaniu i przeszczepianiu komórek, tkanek i narządów (2005). Dz.U. 2005 nr 169 poz. 1411.

Wawrzyniak, J. (2015). Continuation of pregnancy in a woman with critical brain injury. Anaesthesiol Intensive Ther, 47, 40-44. doi: 10.5603/AIT.2015.0005

Woderska, A., Jasinski, M., Arszynska-Lopatka, D., Slupski, M., Janiszewska, T., \& Wlodarczyk, Z. (2012). A brain dead woman, giving birth in the $23^{\text {rd }}$ week of pregnancy, used an organ donor: A case report. Ann Transplant, 17(1), 113-118. doi: 10.12659/aot.882643

Wood, N. S., Marlow, N., Costeloe, K., Gibson, A. T., \& Wilkinson, A. R. (2000). Neurologic and developmental disability after extremely preterm birth. N Engl J Med, 343(6), 378-384.doi: 10.1056/NEJM200008103430601

Wróżyńska, J. (2019) Lekarze odebrali poród - kobieta od 117 dni była w śpiączce ze stwierdzoną śmiercią mózgową. Wysokie Obcasy, 7/12/2019. Retrieved from https://www.wysokieobcasy.pl/wysokie-obcasy/7,163229,25154920,lek arze-odebrali-porod-od-kobiety-ktora-od-117-dni-jest-w-spiaczce.html?disab leRedirects $=$ true 